\title{
People of the Deer Living near Lake Baikal: Dynamics of Ethno-Cultural Identity of Modern Tofalars (Northern Asia, Eastern Siberia)
}

\author{
Victor P. Krivonogov* \\ Siberian Federal University \\ 79 Svobodny, Krasnoyarsk, 660041, Russia
}

Received 22.04.2018, received in revised form 14.08.2018, accepted 16.08.2018

The article presents the results of an integral study of the ongoing ethnic and cultural identification of the Tofalars, an indigenous small-numbered Siberian people who belong to the Turkic group and are concentrated in the Irkutsk Oblast.

The main methods of analysis were repeated interval field studies, comparative studies of the historical dynamics of Tofalars ethnic transformation, critical analysis of scientific sources. The author interprets the obtained results and gives certain forecasts of the ethnic, linguistic and cultural transformation of the Tofalars in the 21st century.

As the main conclusion, it should be noted that the increase in the number of Tofalars has been replaced by stabilization. The Tofalars make up more than half the population in Tofalaria. However, as regards the language, it is on the brink of extinction, the process is irreciprocal, the linguistic indicator is rapidly approaching zero with every decade, as generations change. Due to the limited number of representatives of any other nation, the number of mixed marriages has ceased to grow, and even has begun to decline, but still this indicator remains high. As a result, the share of ethnically and anthropologically mixed population for the Tofalars is on the rise: practically all Tofalars of the younger age groups are mestizoes.

Keywords: Eastern Siberia, Eurasia, indigenous peoples, Tofalars, ethnic identity, cultural identity, linguistic processes, interval studies, field studies, statistics.

Research area: culturology.

Citation: Krivonogov, V.P. (2018). People of the deer living near lake Baikal: dynamics of ethno-cultural identity of modern Tofalars (Northern Asia, Eastern Siberia). J. Sib. Fed. Univ. Humanit. soc. sci., 11(8), 1274-1300. DOI: 10.17516/1997-1370-0306.

\section{Introduction}

"Deer people", or people of the deer, is the self-name of the smallest in number Turkic people of Eastern Siberia - Tofalars, who were called Karagas people in the $19^{\text {th }}$

(c) Siberian Federal University. All rights reserved

* Corresponding author E-mail address: victor950@yandex.ru 
century. The Tofalars belong to the indigenous small-numbered peoples of the North, Siberia and the Far East (Fig. 1) and live in a remote areas - in the Mountain Tofalaria, located in the Irkutsk Oblast of the Russian Federation on the slopes of the of the Eastern Sayan massif, along the rivers Biryusa, Uda, Kan, Gutara, Iya (Fig. 2). Today, Tofalars actively fight for their fundamental rights, including the right to their native land where their ancestors - reindeer herders once roamed (Kerzelli, 1925; Petri, 1927; Pomishin, 1971; Sergeev, 1956). Modern Tofalars make up for a living by fishing and hunting, the northern groups of Tofalars - by reindeer herding. Deer are used by the Tofalars primarily as a means of transport.

The Tofalars today are dissatisfied with regional economic policy, when non-local businessmen enjoy the right to cut down cedar forests on the lands where the Tofalars lived ${ }^{1}$. For the Tofalars these cedar forests are their hunting grounds.

Most Tofalars live compactly in three settlements in the Nizhneudinsk District of the Irkutsk Oblast. This is a very beautiful and isolated mountainous region called Tofalaria. You can get to it by air only. In winter, there are practically no men living in the villages of Tofalaria, as they all go into the taiga for hunting (however, some women are also in hunting). Today this is practically the only source of income for local residents. Tofalaria is abundant with sable, ermine, squirrel, Siberian weasel.

Tofalaria villages are supplied with all the necessary things by air. Therefore, helicopters carry not only people, but also food. Until 1948 industrial gold mining was developed in Tofalaria. After its termination, the region turned into an absolutely subsidized by the state area. The village of Alygdzher is the administrative centre of the Tofalar municipal district. Located on the right bank of the Uda River, 93 kilometres south-west of Nizhneudinsk, Alygdzher (in Tofalar meaning "wind") is cut off by impassable mountains from the "big land". Only a helicopter can be used to reach the village. Winter way is along the frozen riverbed, but this is a rather long (dozens of hours) and insecure journey.

In July 2017, residents of Tofalaria suffered a "transport shock": the Nizhneudinsky District administration cancelled all benefits for air transport between Nizhneudinsk and Tofalaria settlements. Earlier, a ticket for a helicopter to Nizhneudinsk for Tofalaria residents cost 750 rubles, while beneficiaries flew for free. Now they have

Tofalary, kotorykh ostalos' ne bolee 800 chelovek, obratilis' k Putinu - vyrubayut kedrovye lesa na ikh iskonnoj zemle [Tofalars, of which there are no more than 800 people left, appealed to Putin - they cut down the cedar forests on their ancestral land] (2018). In NEWSru.com. Available at: https://realty.newsru.com/ article/01jun2018/tofa 


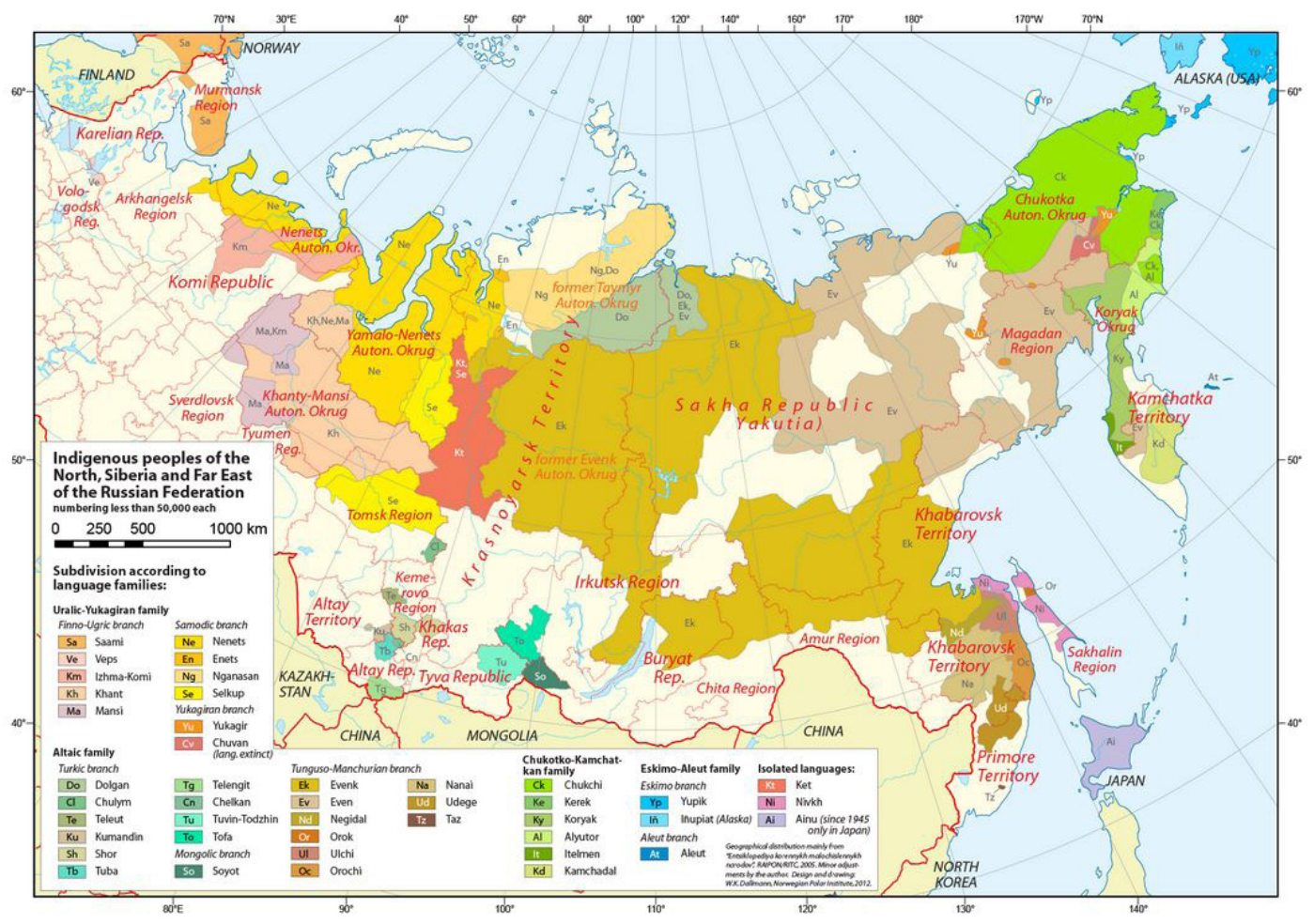

Fig. 1

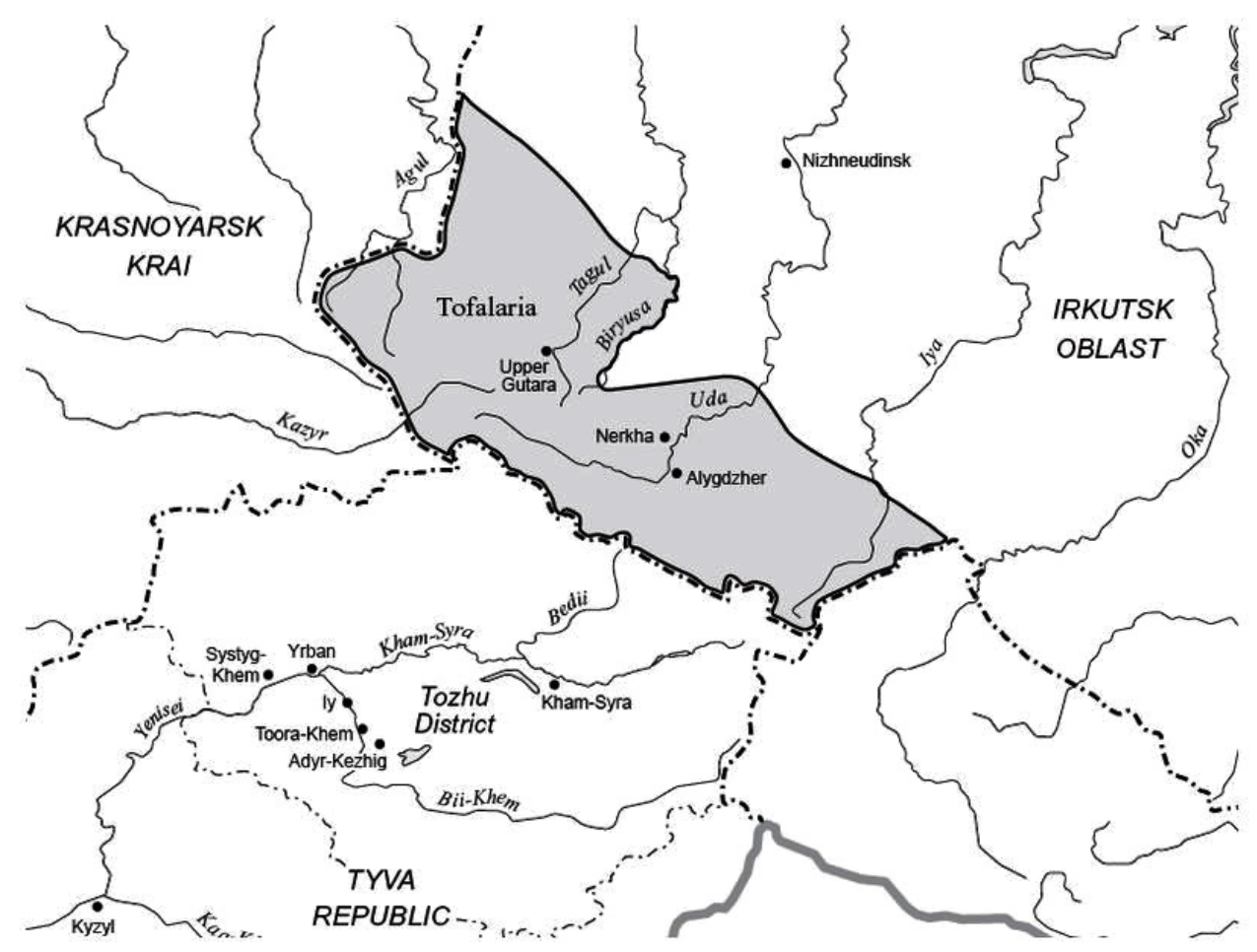

Fig. 2 
established a new fixed cost: the flight to villages Alygdzher and Upper Gutara costs 1500 rubles, while to the Nerkha village - 1300 rubles. At the same time, 7000 rubles is an economically justified ticket price. The difference is compensated by the local budget. Nevertheless, the Tofalars treated an increase in the cost of travel with great concern. They believe that the indigenous small-numbered peoples should have the right for moving for free on their land.

The Tofalar village Upper Gutara has a population of about 400 people. The settlement was established in the 1920s. A little later, there was a kolkhoz "KyzylTofa" ("Red Tofalaria") and a fur farm was founded to breed foxes. The farm soon went bankrupt. Kolkhoz was disbanded in 1967 and included in the Tofalar cooperative fur farm enterprise. In Upper Gutara (as well as in other Tofalar villages) there is no telephone connection, only a radio set. Electricity is made by diesel generators. First planes reached Upper Gutara in 1953 only, before that, all deliveries had been made by the winter road, while in the summer nothing had been delivered to the village, so the population was starving. However, the construction of the airfield had not only positive consequences: the largest meadow with grass was turned into an aerodrome, local cattle breeding suffered because of the fodder reduction.

These cases show that modern Tofalars think of themselves as the indigenous people with specific rights to their territory. The level of ethno-cultural identification of the Tofalars is very high, despite the fact that today it is the smallest one (no more than 800 people) of the Turkic peoples in North Asia.

How did the Tofalars manage to maintain their indigenous identity in conditions when other peoples (for example, the Kereks - the Paleo-Asian Siberian people, the Alyutors - the disappearing Kamchatka people) have already lost this identity? And what is the basis of this identity in the third millennium, the era of globalization and modern technologies?

The purpose of this study is to reveal the dynamic processes of ethno-cultural identification of the Tofalars and current foundations for this identification.

\section{Overview of Tofalar studies}

Southern Siberia and the ethno-cultural groups that inhabit it have long been the subject of numerous scientific studies of various kinds (Vasilevich, Levin, 1951; Dolgikh, 1960; Weinstein, 1960, 1968; Forsyth, 1994; Ziker, 2002, 2003; Donahoe, 2004; Donahoe, Istomin, 2010; Evstrpyeva, 2013). 
Reindeer husbandry as a traditional occupation for the Turkic peoples (including the Tofalars) in Siberia is the topic of lively scientific discussions (Kerzelli, 1925; Kudriavtsev, 1927; Chernyshev 1970; Anderson 1996, 2000; Kuryshov, 2006; Rassadin, 2013).

The Tofalars are analyzed in thorough scientific publications, including a number of monographs focusing on different aspects of their history, language and culture (Dioszegi, 1968; Rassadin, 1966, 1971, 1978, 2015, 2015; Mel'nikova, 1994). The undeniable merit of these works is that they are based on a comprehensive field ethnographic material - a unique source to study folk culture of any ethnos, to expand and deepen understanding of the research problems.

Ethnographic studies of the Tofalars date back to the birth of ethnography in the $19^{\text {th }}$ century. The ancient name of the Tofalars is the Karagas people. Under this name the Tofalars were studied by such scientists as Iu.P. Stubendorf (1854), M.A. Castren (1857), P. Prelovskii (1868-1869), N. Kostrov (1871), A. Kolm (1873), I. Popov (1879), N.M. Astyrev (1889), I. Angarsky (1890, 1891), N.F. Katanov (1891), N.V. Zalesskii (1898), N.V. Vasil'ev (1910), I.A. Evsenin (1916, 1919), K.N. Mirotvortsev (1921), Ia.N. Khodukin, M.E. Zolotarev (1926), B.E. Petri (1926, 1927a, 1927b, 1927c, 1927d, 1928a, 1928b, 1928c), I. Pervukhin (1930), B. Chudinov (1931), Al. Smirnov-Sibirskii (1932a, 1932b), K.H. Menges (1959a, 1959b).

The general ethnological descriptions of Tofalars were made by such researchers as M.A. Sergeev (1940, 1956, 1964), V.P. Krivonogov (1987, 2008, 2016), M.V. Mongush (2012). The peculiarities of the traditional Tofalar economy were analyzed in the works of D. Solov'ev (1920), I.V. Rassadin (2000), M.V. Ragulina (2008). Traditional and modern forms of the Tofalars' social organization were studied by K.D. Harrison, G.D. Anderson (2008), S.A. Bakhtin (2010), S.A. Weinstein (1968, 1970). The Tofalar folklore was recorded and examined in the works of R.A. Sherkhunaev (1975), A.V. Prelovskii (2007), V.I. Rassadin (2013). Linguistic studies were conducted by N.P. Dyrenkova (1963), V.M. Nadeliaev (1969), L.D. Shagdarov (1968). Ethnic transformations of the Tofalars and peculiarities of their health state were investigated by V.P. Krivonogov (1988a, 1988b), L.V. Krivonogova (2007), L.I. Kolesnikova, V.V. Dolgikh， L.F. Sholokhov， E.E. Khramova， O.V. Kravtsova, V.I. Mikhnovich, T.V. Mandziak (2013).

For a long time the Tofalar language has not had a writing system. Creation of the writing language entailing relevant opportunities for the preservation and reproduction of the ethnocultural identity is a scientific feat of the outstanding Russian and Soviet 
ethnolinguist Valentin Ivanovich Rassadin who not only created the Tofalar alphabet and compiled the primer, but also published dictionaries and textbooks for schoolchildren; he also made numerous linguistic studies of the Tofalar language (1965, 1968, 1969, 1972, 1976, 1985, 1989, 1995, 2005, 2008, 2009).

\section{Integral study of the Tofalars}

For the study of modern ethnic processes in different nations, interval research is often used as it is one of the most effective and efficient methods. Repetition of ethnosociological research at specific time intervals (most often once in 10 or 20 years) allows researchers to measure the dynamics of the ongoing ethnic processes and provides data for forecasting. Usually scientific papers refer to only two consecutive studies. But in Tofalaria we managed to carry out four interval studies according to one and the same procedure, respectively in 1985, 1995, 2005 and 2015 (Krivonogov, 1987, 1988a, 1988b, 2008, 2016). The Tofalars after the 1930s transition to a settled way of life live in three villages: Alygdzher, Upper Gutara and Nerkha, included in the Nizhneudinsky District of the Irkutsk Oblast. Tofalaria is the usual name for the southern, mountainous part of the Nizhneudinsky District. Connection with the non-mountainous areas, with the district centre, is mainly carried out by local aviation. In each of the four expeditions, a mass (100-percent coverage) survey of the Tofalar population was conducted with the help of a special ethnographic questionnaire. Besides adults, all children took part in a survey answering questions as retold by their parents in a reduced form. This article outlines the main dynamic indicators of ethnic processes for 4 distinctive times. The main attention is paid to the dynamics of population size, demographic indicators, ethno-linguistic processes, the dynamics of nationally mixed marriage and their consequences, i.e. the process of interethnic and interracial métisation (Krivonogova, 2007).

In addition to the materials of our expeditions, I could obtain information on the number and national composition of Tofalar mixed families for another date -1966 , by processing the household registers stored in local village Soviets. Thus, for over 50 years the dynamics of ethnic processes can be studied. The information on the number and sex-age composition is given in Table 1.

In the years indicated in the table, the total number of Tofalars on their ethnic territory varied: 522, 598, 681, 665 and 663 people. Until 1995, there was a steady increase, followed by a slight decline in number and stabilization. The share of children 
Table 1. Age and sex composition of Tofalars (people)

\begin{tabular}{|l|c|c|c|c|c|c|c|c|c|c|}
\hline \multirow{2}{*}{ age } & \multicolumn{2}{|c|}{1966} & \multicolumn{2}{c|}{1985} & \multicolumn{2}{c|}{1995} & \multicolumn{2}{c|}{2005} & \multicolumn{2}{c|}{2015} \\
\cline { 2 - 11 } & $\mathrm{m}$ & $\mathrm{f}$ & $\mathrm{m}$ & $\mathrm{f}$ & $\mathrm{m}$ & $\mathrm{f}$ & $\mathrm{m}$ & $\mathrm{f}$ & $\mathrm{m}$ & $\mathrm{f}$ \\
\hline 80 and & 1 & 2 & 2 & 4 & 1 & 3 & - & 1 & 1 & - \\
over & & & & & & & & & & \\
$75-79$ & 1 & 3 & - & 3 & 3 & - & - & 3 & - & 1 \\
$70-74$ & 2 & 3 & 5 & 4 & 2 & 4 & 2 & 1 & - & 1 \\
$65-69$ & 6 & 7 & 5 & 5 & 9 & 4 & 6 & 4 & 5 & 4 \\
$60-64$ & 1 & 11 & 2 & 7 & 3 & 4 & 5 & 3 & 17 & 15 \\
$55-59$ & 5 & 6 & 14 & 3 & 11 & 6 & 10 & 8 & 14 & 17 \\
$50-54$ & 9 & 13 & 7 & 6 & 6 & 9 & 27 & 25 & 19 & 21 \\
$45-40$ & 10 & 11 & 13 & 7 & 13 & 9 & 19 & 24 & 12 & 20 \\
$40-44$ & 13 & 13 & 6 & 10 & 36 & 28 & 26 & 23 & 9 & 12 \\
$35-39$ & 21 & 12 & 14 & 10 & 19 & 27 & 16 & 25 & 23 & 30 \\
$30-34$ & 17 & 14 & 37 & 30 & 39 & 29 & 10 & 17 & 39 & 31 \\
$25-29$ & 16 & 16 & 20 & 29 & 22 & 27 & 20 & 32 & 30 & 30 \\
$20-24$ & 7 & 12 & 45 & 30 & 14 & 16 & 47 & 39 & 26 & 23 \\
$15-19$ & 26 & 25 & 23 & 28 & 29 & 40 & 33 & 39 & 28 & 26 \\
$10-14$ & 48 & 39 & 18 & 22 & 62 & 46 & 31 & 30 & 33 & 49 \\
$5-9$ & 32 & 50 & 31 & 48 & 47 & 49 & 27 & 27 & 30 & 39 \\
$0-4$ & 41 & 29 & 62 & 48 & 32 & 32 & 35 & 50 & 24 & 34 \\
\hline Total & 256 & 266 & 304 & 294 & 348 & 333 & 314 & 351 & 310 & 353 \\
\hline
\end{tabular}

under 10 in these years was $29.1 \%, 31.6 \%, 23.5 \%, 20.9 \%$ and $19.2 \%$, respectively. These data indicate a gradual decline in fertility since the mid-1980s.

First of all, the dynamics of the number of Tofalars is affected by the ratio of fertility and mortality. Further, there is external (in relation to Tofalaria) migration departure and return of the Tofalar population. And, finally, the fluctuations in the ethnic consciousness of the mestizo population (sometimes it happens that during their life, under the influence of one or another circumstance, people from mixed families change their previous ethnic self-determination.) In Apart from that, if the children got their ethnic self-identification as told by parents, decades later they can choose a nationality different from what was stated by parents earlier).

How did these three factors affect the number of Tofalars changing between our four studies?

During the first decade (1985-1995), 60 Tofalars died, 164 were born, 45 quit Tofalaria, 27 returned to Tofalaria, 5 people changed their ethnic self-identification from Tofalar to Russian, 2 people changed their ethnic self-identification from Russian to Tofalar. The total number of losses was 110 people, 193 new people appeared, so there was an increase of 83 people. 
During the second decade (1995-2005), 99 Tofalars died, 139 were born, 56 left Tofalaria, 25 went back to Tofalaria, 28 people changed their ethnic self-identification from Tofalar to Russian, 3 people changed their ethnic self-identification from Russian to Tofalar. 183 previously counted people were not found, but 167 new ones appeared, so there was a decrease of 16 people.

In 2015, we recorded 115 deaths and 125 newly born, 62 people left Tofalaria, 21 people returned to Tofalaria, 4 people changed their ethnic self-identification from Tofalar to Russian, 33 people changed their ethnic self-identification from Russian to Tofalar. The population decrease in ten years was 2 people $(-181,+179)$.

During all the studied period, the birth rate consistently decreased (164 - 139 125 people) with increased mortality $(60-99-115$ people). As a result, the natural increase fell down to a minimum (104 - 40 - 10 people), coming very close to zero (natural increase - only 1 person per year!).

Emigration outside the ethnic territory constantly increased ( $45-56-62$ people) with the return flow gradually decreasing $(27-25-21$ people). The negative balance of migration reduced the number of Tofalars for each decade by 18, 31 and 41 people, respectively.

During the studied period the ethnic consciousness of the population was also changing: during the first decade the situation was stable, during the second decade there was a shift in indicators in favour of Russian self-identification, but in the third decade the pendulum was swinging, so the Tofalars self-identification strengthened. In the first decade, due to these fluctuations in self-identification, the Tofalars lost 3

Table 2. National composition of the Tofalar villages (1966, data of economic books)

\begin{tabular}{|l|c|c|c|c|c|c|}
\hline \multirow{2}{*}{} & \multicolumn{2}{|c|}{ Alygdzher } & \multicolumn{2}{c|}{ Nerkha } & \multicolumn{2}{c|}{ Upper Gutara } \\
\cline { 2 - 7 } & people & $\%$ & people & $\%$ & people & $\%$ \\
\hline Tofalars & 227 & 44.7 & 117 & 63.9 & 178 & 50.1 \\
Russians & 269 & 52.9 & 59 & 32.3 & 170 & 47.9 \\
Ukranians & & & & & 1 & \\
Belorussians & 8 & & 1 & & 1 & \\
Tatars & & 2.4 & 1 & 3.8 & & 2.0 \\
Buryats & & & 5 & & 2 & \\
Evenki & 1 & & & & 3 & \\
Komi-Permyaks & 1 & & & & & \\
Koreans & 1 & & & & & \\
Tuvinians & 1 & & 183 & 100 & 355 & 100 \\
Estonians & 508 & 100 & & &
\end{tabular}


Table 3. National composition of the Tofalar villages (1985)

\begin{tabular}{|l|c|c|c|c|c|c|}
\hline \multirow{2}{*}{} & \multicolumn{2}{|c|}{ Alygdzher } & \multicolumn{2}{c|}{ Nerkha } & \multicolumn{2}{c|}{ Upper Gutara } \\
\cline { 2 - 7 } & people & $\%$ & people & $\%$ & people & $\%$ \\
\hline Tofalars & 231 & 42.4 & 143 & 74.5 & 224 & 65.9 \\
Russians & 300 & 55.0 & 44 & 22.9 & 106 & 31.2 \\
Ukranians & 4 & & 2 & & 4 & \\
Tatars & 5 & & - & & 1 & \\
Buryats & 4 & & 1 & & - & 2.9 \\
Evenki & - & & 1 & & 2 & \\
Germans & - & 2.6 & 1 & 2.6 & - & \\
Komi-Permyaks & 1 & & - & & - & \\
Aghuls & - & & - & & 1 & \\
Belorussians & - & & - & & 1 & \\
Koreans & - & & - & & 1 & \\
& 545 & 100 & 192 & 100 & 340 & 100 \\
\hline Total & & & & & \\
\hline
\end{tabular}

Table 4. National composition of the Tofalar villages (1995)

\begin{tabular}{|l|c|c|c|c|c|c|}
\hline \multirow{2}{*}{} & \multicolumn{2}{|c|}{ Alygdzher } & \multicolumn{2}{c|}{ Nerkha } & \multicolumn{2}{c|}{ Upper Gutara } \\
\cline { 2 - 7 } & people & $\%$ & people & $\%$ & people & $\%$ \\
\hline Tofalars & 250 & 47.0 & 168 & 70.9 & 263 & 65.6 \\
Russians & 273 & 51.3 & 62 & 26.2 & 128 & 31.9 \\
Ukranians & 4 & & 2 & & 3 & \\
Tatars & 2 & & - & & 2 & \\
Buryats & 2 & & 2 & & - & \\
Evenki & - & & 1 & & 2 & \\
Germans & - & & 1 & & - & \\
Aghuls & - & 1.7 & - & 2.9 & 1 & 2.5 \\
Chuvashes & 1 & & - & & - & \\
Khakasses & - & & 1 & & - & \\
Belorussians & - & & 1 & & 1 & \\
Mordvins & - & & 1 & & 401 & 100 \\
\hline Total & 532 & 100 & 237 & & & \\
\hline
\end{tabular}

people, in the second -25 , but in the third decade for this reason the growth in the number of Tofalars was 29 people, so there is no loss by this indicator for the whole period of studies.

Changes in the number of Tofalars, as well as in the national composition of Tofalar villages, are shown in Tables 2-6.

In the largest settlement of Alygdzher, with all the fluctuations during 50 years, the share of the Tofalars remained the same, amounting to a little less than half the population of this village. In Nerkha, the share was stable - at about $70 \%$, in Upper Gutara there was a continuous increase in the share of the Tofalars starting from half 
Table 5. National composition of the Tofalar villages (2005)

\begin{tabular}{|l|c|c|c|c|c|c|}
\hline \multirow{2}{*}{} & \multicolumn{2}{|c|}{ Alygdzher } & \multicolumn{2}{c|}{ Nerkha } & \multicolumn{2}{c|}{ Upper Gutara } \\
\cline { 2 - 7 } & people & $\%$ & people & $\%$ & people & $\%$ \\
\hline Tofalars & 228 & 43.8 & 149 & 69.0 & 288 & 65.2 \\
Russians & 282 & 54.1 & 62 & 28.7 & 145 & 32.8 \\
Ukranians & 3 & & 3 & & 5 & \\
Tatars & 6 & & - & & - & \\
Buryats & 1 & & - & & - & \\
Evenki & - & & - & & 2 & \\
Germans & - & 2.1 & 2 & 2.3 & - & 2.0 \\
Nenets & 1 & & - & & - & \\
Koryaks & - & & - & & 1 & \\
Aghuls & - & & - & & 1 & \\
\hline Total & 521 & 100 & 216 & 100 & 442 & 100 \\
\hline
\end{tabular}

Table 6. National composition of the Tofalar villages (2015)

\begin{tabular}{|l|c|c|c|c|c|c|}
\hline \multirow{2}{*}{} & \multicolumn{2}{|c|}{ Alygdzher } & \multicolumn{2}{c|}{ Nerkha } & \multicolumn{2}{c|}{ Upper Gutara } \\
\cline { 2 - 7 } & people & $\%$ & people & $\%$ & people & $\%$ \\
\hline Tofalars & 237 & 45.5 & 159 & 69.7 & 267 & 71.6 \\
Russians & 279 & 53.6 & 64 & 28.1 & 103 & 27.6 \\
Ukranians & 1 & & 3 & & 1 & \\
Tatars & 2 & & - & & - & \\
Buryats & 1 & 0.9 & 2 & 2.2 & - & 0.8 \\
Nenets & 1 & & - & & - & \\
Koryaks & - & & - & & 1 & \\
Aghuls & - & & - & & 1 & \\
\hline Total & 521 & 100 & 228 & 100 & 373 & 100 \\
\hline
\end{tabular}

Table 7. Dynamics for the main nationalities of Tofalaria

\begin{tabular}{|l|c|c|c|c|c|c|c|c|c|c|}
\hline \multirow{2}{*}{} & \multicolumn{2}{|c|}{1966} & \multicolumn{2}{c|}{1985} & \multicolumn{2}{c|}{1995} & \multicolumn{2}{c|}{2005} & \multicolumn{2}{c|}{2015} \\
\cline { 2 - 11 } & people & $\%$ & people & $\%$ & people & $\%$ & people & $\%$ & people & $\%$ \\
\hline Tofalars & 522 & 49.9 & 598 & 55.5 & 681 & 58.2 & 665 & 56.4 & 663 & 59.1 \\
Russians & 498 & 47.6 & 450 & 41.8 & 463 & 39.6 & 489 & 41.5 & 446 & 39.7 \\
Other & 26 & 2.5 & 29 & 2.7 & 26 & 2.2 & 25 & 2.1 & 13 & 1.2 \\
\hline Total & 1046 & 100 & 1077 & 100 & 1170 & 100 & 1179 & 100 & 1122 & 100 \\
\hline
\end{tabular}

of the population, and exceeding 70\% in the end. Previously, the majority of Tofalars in absolute terms had lived in Alygdzher, but later Upper Gutara outperformed this indicator (now 267 against 237 people). The highest proportion of Tofalars was always recorded in the smallest village - Nerkha, but more recently Upper Gutara has outperformed Nerkha, too (71.6\% against $69.7 \%)$. 
The number of Russians sometimes decreased, then increased, but in general, for half a century it somewhat declined, as well as the number of other newly-arrived nationalities (Table 7). The number of Tofalars also fluctuated, but nevertheless there is a noticeable tendency to increase, as over half a century their share grew from 50 to $60 \%$.

Despite some predominance of the Tofalars in the population of the mountainous country, all three villages are mixed by national composition, so the language of interethnic communication is Russian. Four consecutive surveys showed a continuous decrease in all indicators of the Tofalar language (Table 8). Since the 1990s, the Tofalar language has been studied in the primary school, but this has not changed the situation. The Tofalar language is quickly disappearing and replaced by Russian. Less and less Tofalars name this language as their native and even less people use it in real life (Table 9). So far it has been called as native by $5.9 \%$ of the Tofalar families with only $0.5 \%$ using it in communication. When our expedition visited Tofalaria for the first time, in 1985, we often heard the Tofalar speech in the streets of settlements, in stores, etc., but during our last visit we never heard people speaking Tofalar. In Upper Gutara, the last two reindeer herders - the Kholiamoev brothers, Valery and Viacheslav, who know the language well, admitted that in the taiga, near their flock, they communicate with each other in Tofalar, but when they visit the village, both switch to Russian immediately.

Between the three villages there are small differences in the level of knowledge of the Tofalar language, but these differences are not fundamental, the constant language attrition has been fixed from the survey to the survey in all the villages.

The decrease in the language proficiency is revealed not only when we compare the indicators for different years, but also when we compare linguistic indicators in different age groups. We will show this by the example of the last study (Table 10).

Data on the native language are consistent with data on the level the Tofalar language knowledge (Table 11). As early as in 1985, only one of four respondents was fluent in Tofalar, by now only $3.3 \%$ people are able to speak this language. As for the Russian language, almost all Tofalars have learned it.

Data on the level of fluency in Tofalar, distributed by age group, indicate that not only children, but also middle-aged people are not able to speak the language very well (Table 12).

In absolute numbers, the number of people fluent in the Tofalar language fell to 22 people. All of them are elderly and their departure from life predetermines the fate of the language. 
Table 8. Native language of the Tofalars (survey, \%)

\begin{tabular}{|l|c|c|c|}
\hline \multirow{2}{*}{} & \multicolumn{3}{|c|}{ Native language } \\
\cline { 2 - 4 } & Tofalar & Tofalar and Russian & Russian \\
\hline 1985 & 29.9 & 5.0 & 65.1 \\
1995 & 16.1 & 5.3 & 78.6 \\
2005 & 8.3 & 4.5 & 87.2 \\
2015 & 3.3 & 2.6 & 94.1 \\
\hline
\end{tabular}

Table 9. The main spoken language of the Tofalars (survey, \%)

\begin{tabular}{|l|c|c|c|}
\hline \multirow{2}{*}{} & \multicolumn{3}{|c|}{ Main spoken language } \\
\cline { 2 - 4 } & Tofalar & Tofalar and Russian & Russian \\
\hline 1985 & 6.9 & 6.8 & 86.3 \\
1995 & 2.8 & 4.8 & 92.4 \\
2005 & 0.3 & 1.2 & 98.5 \\
2015 & - & 0.5 & 99.5 \\
\hline
\end{tabular}

Table 10. The native language of the Tofalars in different age groups (survey, 2015, \%)

\begin{tabular}{|l|c|c|c|}
\hline \multicolumn{1}{|c|}{ Age } & Tofalar & Tofalar and Russian & Russian \\
\hline 70 and over & 66.7 & - & 33.3 \\
$60-69$ & 26.8 & 17.1 & 56.1 \\
$50-59$ & 7.0 & 11.3 & 81.7 \\
$40-49$ & 3.8 & - & 96.2 \\
$30-39$ & 0.8 & 0.8 & 98.4 \\
$20-29$ & 0.9 & - & 99.1 \\
$10-19$ & - & 0.7 & 99.3 \\
under 10 & - & - & 100 \\
\hline
\end{tabular}

Table 11. Level of the Tofalar language knowledge (survey, \%)

\begin{tabular}{|l|c|c|c|c|c|}
\hline \multirow{2}{*}{} & \multicolumn{5}{|c|}{ Speak the Tofalar language } \\
\cline { 2 - 6 } & Fluently & $\begin{array}{c}\text { With some } \\
\text { difficulties }\end{array}$ & $\begin{array}{c}\text { With certain } \\
\text { difficulties }\end{array}$ & $\begin{array}{c}\text { Understand } \\
\text { only }\end{array}$ & Do not speak \\
\hline 1985 & 25.1 & 8.7 & 7.9 & 18.7 & 39.6 \\
1995 & 14.4 & 5.1 & 9.0 & 18.4 & 53.1 \\
2005 & 9.2 & 3.3 & 7.1 & 15.5 & 64.9 \\
2015 & 3.3 & 1.5 & 5.0 & 12.2 & 78.0 \\
\hline
\end{tabular}

The Russian language prevails not only in communication with other nationalities, but also within the Tofalar families themselves. Younger generation more often uses the Tofalar language in communication with their parents, however, the relevant indicators fell below 10\% (Table 13-18). For other age groups the use of the Tofalar language 
Table 12. Level of the Tofalar language knowledge in different age groups (survey, 2015, \%)

\begin{tabular}{|l|c|c|c|c|c|}
\hline \multirow{2}{*}{} & \multicolumn{5}{|c|}{ Speak the Tofalar language } \\
\cline { 2 - 6 } & Fluently & $\begin{array}{c}\text { With some } \\
\text { difficulties }\end{array}$ & $\begin{array}{c}\text { With certain } \\
\text { difficulties. }\end{array}$ & $\begin{array}{c}\text { Understand } \\
\text { only }\end{array}$ & Do not speak \\
\hline 70 and over & 66.7 & 33.3 & - & - & - \\
$60-69$ & 29.3 & 12.2 & 14.6 & 24.4 & 19.5 \\
$50-59$ & 9.9 & 4.2 & 22.5 & 33.8 & 29.6 \\
$40-49$ & 1.9 & - & 13.2 & 32.1 & 52.8 \\
$30-39$ & - & 0.8 & 2.4 & 16.3 & 80.5 \\
$20-29$ & - & - & 0.9 & 7.3 & 91.8 \\
$10-19$ & - & - & - & 1.5 & 98.5 \\
under 10 & - & - & - & - & 100 \\
\hline
\end{tabular}

Table 13. Main languages used by the Tofalars in communication with their parents (survey, \%)

\begin{tabular}{|l|c|c|c|}
\hline & Tofalar & Tofalar and Russian & Russian \\
\hline 1985 & 23.3 & 14.3 & 62.4 \\
1995 & 12.2 & 14.5 & 73.3 \\
2005 & 5.3 & 11.0 & 83.7 \\
2015 & 1.8 & 6.8 & 91.4 \\
\hline
\end{tabular}

Table 14. Main languages used by the Tofalars in communication with their brothers and sisters (survey, \%)

\begin{tabular}{|l|c|c|c|}
\hline & Tofalar & Tofalar and Russian & Russian \\
\hline 1985 & 11.3 & 11.9 & 76.8 \\
1995 & 4.8 & 8.4 & 86.8 \\
2005 & 2.1 & 5.0 & 92.9 \\
2015 & 0.6 & 2.4 & 97.0 \\
\hline
\end{tabular}

Table 15. Main languages used by the Tofalars in communication with their friends (survey, \%)

\begin{tabular}{|l|c|c|c|}
\hline & Tofalar & Tofalar and Russian & Russian \\
\hline 1985 & 6.1 & 22.8 & 71.1 \\
1995 & 0.9 & 14.2 & 84.9 \\
2005 & 0.3 & 10.1 & 89.6 \\
2015 & 0.2 & 3.9 & 95.9 \\
\hline
\end{tabular}

Table 16. Main languages used by the Tofalars in communication with their spouses (survey, \%)

\begin{tabular}{|l|c|c|c|}
\hline & Tofalar & Tofalar and Russian & Russian \\
\hline 1985 & 22.5 & 9.1 & 68.4 \\
1995 & 10.4 & 9.6 & 80.0 \\
2005 & 2.5 & 5.6 & 91.9 \\
2015 & 0.3 & 1.8 & 97.9 \\
\hline
\end{tabular}


Table 17. Main languages used by the Tofalars in communication with their children (survey, \%)

\begin{tabular}{|l|c|c|c|}
\hline & Tofalar & Tofalar and Russian & Russian \\
\hline 1985 & 7.2 & 15.0 & 77.8 \\
1995 & 1.2 & 8.4 & 90.4 \\
2005 & 1.4 & 3.1 & 95.5 \\
2015 & - & 0.7 & 99.3 \\
\hline
\end{tabular}

Table 18. Main languages used by the Tofalars in communication at work (survey, \%)

\begin{tabular}{|c|c|c|c|}
\hline & Tofalar & Tofalar and Russian & Russian \\
\hline 1985 & 3.9 & 23.8 & 72.3 \\
1995 & 1.4 & 16.3 & 82.3 \\
2005 & 0.8 & 5.3 & 93.9 \\
2015 & - & 1.7 & 98.3 \\
\hline
\end{tabular}

Table 19. National composition of Tofalar families

\begin{tabular}{|l|c|c|c|c|c|}
\hline \multicolumn{1}{|c|}{ Families } & 1966 & 1985 & 1995 & 2005 & 2015 \\
\hline Marriage to a person of the same nationality & 79 & 90 & 101 & 112 & 117 \\
Mixed marriages & 34 & 75 & 88 & 85 & 81 \\
including & & & & & \\
- to Buryats & 1 & 2 & 2 & - & 2 \\
- to Evenki & - & 3 & 3 & 1 & - \\
- to Khakasses & - & - & 1 & - & - \\
- to Koryaks & 1 & 1 & - & 1 & 1 \\
- to Koreans & 28 & 60 & - & - & - \\
- to Russians & - & 5 & 6 & 76 & 75 \\
- to Ukranians & 1 & 1 & 1 & - & 2 \\
- to Belorussians & - & 1 & 1 & 1 & - \\
- to Germans & - & 1 & 1 & 1 & - \\
- to Tatars & - & - & 1 & - & - \\
- to Mordvins & - & - & 1 & - & - \\
- to Chuvashes & 1 & 1 & - & - & - \\
- to Komi-Permyaks & 1 & - & - & - & - \\
- to Tuvinians & 30.1 & 45.5 & 46.6 & 43.1 & 40.9 \\
\hline \% of nationally mixed marriages & & & & \\
\hline
\end{tabular}

reduced to $1-2 \%$ of the respondents. In younger age groups this language is not spoken at all.

Nationally mixed marriages exert a significant influence on the ethnic processes, especially this concerns small-numbered peoples. From the 1960 s to the 1980 s, the number of such marriages increased rapidly, but then the growth stabilized and stopped, but at a very high level (Table 19). Stabilization occurred as a result of a small number of potential marriage partners of other nationalities. As there are not so many non-aboriginal people, the growth stopped, having reached the maximum theoretical probability. 
Table 20. National composition of the Tofalar couples in 1966

\begin{tabular}{|l|c|c|c|c|c|c|c|c|c|}
\hline & Tofalars & Buryats & Evenki & Tuvinians & Russians & $\begin{array}{c}\text { Komi- } \\
\text { Permyaks }\end{array}$ & $\begin{array}{c}\text { Belorus- } \\
\text { sians }\end{array}$ & Koreans & $\begin{array}{c}\% \text { mixed } \\
\text { marriages }\end{array}$ \\
\hline Male & 49 & 1 & 1 & 1 & 19 & & & 1 & 31.9 \\
\hline Female & 49 & & & & 7 & 1 & 1 & & 15.5 \\
\hline
\end{tabular}

Table 21. National composition of the Tofalar couples in 1985

\begin{tabular}{|c|c|c|c|c|c|c|c|c|}
\hline & Tofalars & Buryats & Evenki & Russians & Ukranians & $\begin{array}{c}\text { Komi- } \\
\text { Permyaks }\end{array}$ & Germans & $\begin{array}{c}\% \text { mixed } \\
\text { marriages }\end{array}$ \\
\hline Male & 47 & 1 & & 25 & 2 & & & 37.3 \\
\hline Female & 47 & & 2 & 30 & 2 & 1 & 1 & 43.4 \\
\hline
\end{tabular}

Table 22. National composition of the Tofalar couples in 1995

\begin{tabular}{|c|c|c|c|c|c|c|c|c|c|c|c|c|}
\hline & 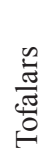 & 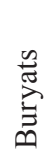 & 咅 & 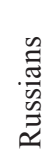 & 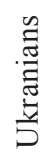 & 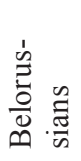 & $\begin{array}{l}\text { 岕 } \\
\text { 岕 }\end{array}$ & 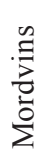 & 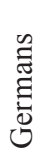 & 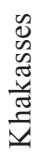 & 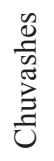 & 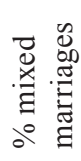 \\
\hline Male & 60 & 1 & & 22 & 1 & 1 & 1 & & & & 1 & 31.0 \\
\hline Female & 60 & & 2 & 39 & 5 & & & 1 & 1 & 1 & & 45.0 \\
\hline
\end{tabular}

Table 23. National composition of the Tofalar couples in 2005

\begin{tabular}{|l|c|c|c|c|c|c|c|c|}
\hline & Tofalars & Koryaks & Evenki & Russians & Ukranians & Tatars & Germans & $\begin{array}{c}\% \text { mixed } \\
\text { marriages }\end{array}$ \\
\hline Male & 73 & & & 22 & 1 & & & 24.0 \\
\hline Female & 73 & 1 & 1 & 47 & 2 & 1 & 1 & 42.1 \\
\hline
\end{tabular}

Table 24. National composition of the Tofalar couples in 2015

\begin{tabular}{|l|c|c|c|c|c|c|c|}
\hline & Tofalars & Koryaks & Buryats & Russians & Ukranians & Tatars & $\begin{array}{c}\% \text { mixed } \\
\text { marriages }\end{array}$ \\
\hline Male & 68 & & & 19 & 1 & & 22.7 \\
\hline Female & 68 & 1 & 1 & 48 & 1 & 1 & 43.3 \\
\hline
\end{tabular}

Data on the total number of mixed marriages are supplemented by figures describing the national composition of married couples (Tables 20-24).

As for men, the number of marriages to women of other nationalities had grown until 1985, but then this indicator began to decline. In the past, the number of mixed 
Table 25. Dynamics of the Tofalar population métisation and mestizo types (survey data)

\begin{tabular}{|l|c|c|c|c|}
\hline \multirow{2}{*}{} & \multirow{2}{*}{ Pureblood } & \multicolumn{3}{|c|}{ Mestizo types } \\
\cline { 3 - 5 } & 214 & $\begin{array}{c}\text { Mixed with } \\
\text { Mongoloid }\end{array}$ & $\begin{array}{c}\text { Mixed with Mongoloid } \\
\text { and European }\end{array}$ & Mixed with European \\
\hline 1985, people & 25 & 47 & 312 \\
\hline$\%$ & 35.8 & 4.2 & 7.8 & 52.2 \\
\hline 1995, people & 202 & 26 & 79 & 374 \\
\hline$\%$ & 29.7 & 3.8 & 11.6 & 54.9 \\
\hline 2005, people & 148 & 22 & 110 & 385 \\
\hline$\%$ & 22.3 & 3.3 & 16.5 & 57.9 \\
\hline 2015, people & 83 & 22 & 144 & 614 \\
\hline$\%$ & 12.5 & 3.3 & 21.7 & 62.5 \\
\hline
\end{tabular}

Table 26. The share of mestizoes in different Tofalar age groups in 2015

\begin{tabular}{|l|c|c|c|c|}
\hline & $1^{*}$ & $2^{*}$ & $3^{*}$ & $4^{*}$ \\
\hline 80 and over & 100 & - & - & - \\
$70-79$ & - & 50 & - & 50 \\
$60-69$ & 29.3 & - & 4.9 & 65.8 \\
$50-59$ & 29.6 & 8.4 & 11.3 & 50.7 \\
$40-49$ & 24.5 & 9.5 & 9.4 & 56.6 \\
$30-39$ & 7.3 & 3.3 & 19.5 & 69.9 \\
$20-29$ & 15.6 & - & 23.8 & 60.6 \\
$10-19$ & 7.3 & 1.5 & 34.6 & 56.6 \\
under 10 & - & 3.1 & 25.2 & 71.7 \\
\hline
\end{tabular}

*1 - Purebred Tofalars; 2 - Mixed with Mongoloid; 3 - Mixed with Mongoloid and European; 4 - Mixed with European.

marriages for men was double the number of mixed marriages for women, but this share for women rose faster, so women had overtaken men in this matter by 1985 . And in the future, unlike the situation for men, the number of such marriages for women instead of decreasing stabilized at a point above $40 \%$.

Although there was stable proportion of mixed marriages, the percentage of the mestizo population continued to grow further (Table 25), as people of mixed origin (they are considered to be of the same nationality though) married each other, therefore the mestizo children were born not so much in mixed families, but in such families where parents had the same national identity. The proportion of mestizoes among Tofalars approximated to $90 \%$, and among children it reached $100 \%$.

214 people declared themselves purebloods at the beginning of our studies, and they accounted for $35.8 \%$ of the people, but now the number of purebloods is 83 people only $(12.5 \%)$. 
Table 27. Dynamics of the Europeoids share among the Tofalars

\begin{tabular}{|l|c|c|c|c|}
\hline \multirow{2}{*}{} & \multicolumn{4}{|c|}{ Europeoids share } \\
\cline { 2 - 5 } & no & less than $1 / 2$ & $1 / 2$ & over $1 / 2$ \\
\hline 1985 & 40.0 & 15.9 & 28.4 & 15.7 \\
1995 & 33.5 & 18.8 & 29.8 & 17.9 \\
2005 & 25.6 & 19.5 & 34.1 & 20.8 \\
2015 & 15.8 & 24.3 & 34.7 & 25.2 \\
\hline
\end{tabular}

Table 28. Share of Europeoid mestizoes in different Tofalar age groups in 2015 (\%)

\begin{tabular}{|l|c|c|c|c|}
\hline \multirow{2}{*}{ Age } & \multicolumn{4}{|c|}{ Europeoids share } \\
\cline { 2 - 5 } & no & less than $1 / 2$ & $1 / 2$ & over $1 / 2$ \\
\hline 80 and over & 100 & - & - & - \\
$70-79$ & 50 & - & 50 & - \\
$60-69$ & 29.3 & 21.9 & 41.5 & 7.3 \\
$50-59$ & 38.0 & 18.3 & 39.5 & 4.2 \\
$40-49$ & 34.0 & 17.0 & 41.5 & 7.5 \\
$30-39$ & 10.6 & 27.6 & 33.3 & 28.5 \\
$20-29$ & 15.6 & 25.7 & 37.6 & 21.1 \\
$10-19$ & 8.8 & 26.5 & 29.4 & 35.3 \\
$0-9$ & 3.1 & 25.2 & 31.5 & 40.2 \\
\hline
\end{tabular}

Of the people of mixed origin, the overwhelming majority attribute themselves to the Tofalars. As for two-parent families with children, in 1985 96.0\% of children were recorded as the Tofalars, in 1995 this number dropped slightly to $95.5 \%$, in 2005 - to $79.6 \%$, in 2015 it increased to $85.1 \%$. Doing the survey, we included in the Tofalars only those mestizoes who attributed themselves to this nationality, and from children those whom their parents named the Tofalars.

The predominance of the ethnic self-identification is associated with the stability of the national self-awareness of Tofalars, also supported by various state benefits for the indigenous minorities of the North. In 2005, our survey showed a certain weakening of ethnic self-awareness, mainly because of mestizoes who have a small number of the Tofalar ancestors, but next the hope for state benefits made Tofalar self-identification the preferred one once again.

Data on the composition of different age groups show the dynamic progress of the métisation process. Younger age groups have literally no purebred Tofalars.

Some mestizoes come from mixed families (when the Tofalars get married to neighbouring Siberian peoples (Tuvans, Evenks, Buryats)). Their appearance is practically no different from purebred Tofalars, but their number is a little more than $3 \%$ only, whereas the children in other mixed families (one parent is of the Russian or 
other European nation origin) differ in appearance. It should be said that the Europeoid component is distributed unevenly among Tofalars, e.g., there are half Europeans (for example, from families where the father is Russian and the mother is Tofalar), three quarters Europeans (for example, from families where the father is Russian and the mother is a mestizo), or one-fourth Europeans (one of the spouses is a mestizo, the second is a purebred Tofalar). This is shown in Table 27.

From study to study, the number of Europeoid mestizoes with different proportions of the Europeoid ancestors is increasing, and now for every fourth Tofalar the Europeoid component in exceeds the aboriginal one $(25.2 \%$ by 2015). Table 28 shows how the Europeoid genetic background grows from the older age groups to the younger ones.

Now most of the children look more like Russians.

\section{Conclusion}

Summarizing, I can say that the Tofalars undergo processes that are characterized by the following. Decrease in natural population growth and departure from their traditional ethnic territory could have significantly reduced the number of Tofalars, but this loss is compensated by the high level of Tofalar self-identification of the mestizo population. As a result, the growth in the number of Tofalars was driven out by stabilization. The share of the Tofalar population among the village inhabitants is the same, the Tofalars make up more than half of the population in Tofalaria. However, with regard to linguistic parameter, one can observe rapid language attrition, the processes here are irreversible: with every decade the language knowledge is increasingly approaching zero with the change of generations. Due to the limited number of nonaboriginal people, the number of mixed marriages has ceased to grow and even has begun to decline, still remaining at a relatively high level. As a result, the share of ethnically and anthropologically mixed population is booming among the Tofalars, in the younger age groups almost all Tofalars are mestizoes.

The Tofalars quickly and irrevocably turn into a group of Russian-speaking mestizoes, though retaining a stable specific national identity. Maintaining this special ethnic identity is facilitated by a relatively small number of newcomers, steady adherence of the indigenous population to traditional occupations in taiga, and state support for small-numbered peoples. 


\section{References}

Anderson, D.G. (1996). Bringing civil society to an uncivilised place, In Civil Society: Challenging Western Models, 99-120.

Anderson, D.G. (2000). Identity and ecology in Arctic Siberia: the number one reindeer brigade. Oxford University Press.

Angarsky, I. (1891). Zapiski o karagasakh [Notes on Karagas people], In Vostochnoe obozrenie [Eastern Review], 6. Saint-Petersburg.

Astyrev, N.M. (1889). O chislennosti i promyslakh plemeni karagasov [On the number and occupations of the Karagas tribe], In Izvestiia Vostochno-Sibirskogo otdeleniia Russkogo geograficheskogo obshchestva [Journal of the East Siberian Branch of the Russian Geographical Society], 20, 2.

Astyrev, N.M. (1890). Ocherk byta plemeni karagasov Nizhneudinskogo okruga [Review on the way of life of the Karagas tribe in the Nizhneudinsky District], In Materialy po issledovaniiu zemlepol'zovaniia $i$ khoziaistvennogo byta sel'skogo naseleniia Irkutskoi $i$ Eniseiskoi gubernii [Materials on the study of land use and economic life of the rural population in Irkutsk and Yeniseysk Governorates], 2, 2, 1. Moscow.

Bakhtin, S.A. (2010). Etnicheskaia identichnost' tofalarov v nachale XXI veka [Ethnic identity of the Tofalars at the beginning of the $21^{\text {st }}$ century], In Problemy istorii, filologii, kul'tury [Issues of history, philology, culture], 3 (29), 322-327.

Bannikov, K.L., Kuznetsova, E.A. (2004). V beskonechnosti nevoploshchennykh smyslov: mysli o tofalarskoi gline [In infinity of unembodied meanings: thoughts about Tofalar clay], In Nauka iz pervykh ruk [Science first-hand], 2 (3), 136-149.

Castren, M.A. (1857). Versuch einer koibalischen und Karagassischen Sprachleh renebst Worterverzeichnissenaus den tatarischen Mundarten des Minussinischen Kreises. Saint-Petesburg.

Chernyshev, B. (1970). V strane Tofalarii [In the country of Tofalaria], In Baikal, 2. Ulan-Ude.

Chudinov, B. (1931). Puteshestvie po Karagassii [Journey through the Karagas land]. Moscow.

Dioszegi, V. (1968). The Problem of the Homogeneity of Tofa (Karagas) Shamanism, In Popular Beliefs and folklore Tradition on Siberia. Bloomington, Indiana University Publications, 239-330.

Dolgikh, B.O. (1960). Rodovoi i plemennoi sostav narodov Sibiri v XVII v. [The kin and tribal composition of the peoples in Siberia in the $17^{\text {th }}$ century], In Trudy 
Instituta etnografii. Novaia seriia [Proceedings of the Institute of Ethnography. New Series], 55.

Donahoe, B., Istomin, K.V. (2010). Izmenenie praktiki regulirovaniia dostupa $\mathrm{k}$ prirodnym resursam u nekotorykh olenevodcheskikh narodov Sibiri. Popytka teoreticheskogo obobshcheniia [Changes in regulating access to natural resources for some reindeer herding peoples of Siberia. Attempt of theoretical generalization], In Novye issledovaniia Tuvy [New research of Tuva], 4 (8), 55-119.

Donahoe, B.R. (2004). A line in the Sayans: History and divergent perceptions of property among the Tozhu and Tofa of South Siberia. Bloomington, Indiana University.

Dyrenkova, N.P. (1963). Tofalarskii iazyk [Tofalar language], In Tiurkologicheskie issledovaniia [Turkology studies], 5-23. Moscow

Evsenin I. (1916). Buriaty o karagasakh [The Buryats about the Karagas people], In Sibirskaia letopis' [Siberian Chronicle], 9-10. Krasnoyarsk.

Evsenin, I.A. (1919). Karagassy. (Kratkii ocherk) [Karagas people. (A short review)]. Krasnoyarsk.

Evstrpyeva, O. (2013). The resources of endogenous tourism of the Baikal Region, In International Journal for Responsible Tourism, 2.3, 54-62.

Forsyth, J. (1994). A history of the peoples of Siberia: Russia's North Asian colony 1581-1990. Cambridge University Press.

Harrison, K.D., Anderson G.D. (2008). Tofa language change and terminal generation speakers, In Lessons from Documented Endangered Languages, 78, 243-270.

Katanov, N.F. (1891). Poezdka k karagasam v 1890 g. [Trip to the Karagas people in 1890], In Zapiski Imperatorskogo Russkogo geograficheskogo obshchestva po otdeleniu etnografii [Notes of the Imperial Russian Geographical Society (the department of. ethnography)], 17, 2.

Kerzelli, S.V. (1925). Karagasskii olen' i ego khoziaistvennoi znachenie [Karagas deer and its economic significance], In Severnaia Aziia [Northern Asia], 3. Moscow.

Khodukin, Ia.N., Zolotarev, M.E. (1926). Karagasiia. Materialy Irkutskogo Mestnogo Komiteta Severa [Karagas land. Materials of the Irkutsk Local Committee of the North].

Kolesnikova, L.I., Dolgik, V.V., Sholokhov, L.F., Khramova, E.E., Kravtsova, O.V., Mikhnovich, V.I., Mandziak, T.V. (2013). Osobennosti somaticheskogo i reproduktivnogo zdorov'ia detei i podrostkov Tofalarii [Features of somatic and reproductive health among children and adolescents of Tofalaria], In Acta Biomedica Scientifica, 4 (92), 32-35. 
Kolm, A. (1873). Die Karagasen des kleinen Altaigebirges, In Globus, 4.

Kostrov, N. (1871). Karagasy [The Karagas people], In Illiustrirovannaia gazeta [Illustrated newspaper], 43-44. Saint-Petersburg.

Krivonogov, V.P. (1987). K sovremennoi etnicheskoi situatsii v Tofalarii [On the modern ethnic situation in Tofalaria], In Sovetskaia etnografiia [Soviet ethnography], 5, 81-90.

Krivonogov, V.P. (1988a). "Demograficheskii vzryv" u tofalarov ["Population explosion" of the Tofalars], In Istoriografiia i istoriia izucheniia istoricheskogo opyta osvoenia Sibiri [Historiography and history of studying the historical experience of the Siberia development], 23-24. Novosibirsk.

Krivonogov, V.P. (1988b). K metodike izucheniia etnicheskikh i kul'turnykh protsessov v Tofalarii [On the methodology of studying ethnic and cultural processes in Tofalaria], In Istochniki i metody issledovaniia sotsial'nykh i kul'turnykh protsessov [Sources and methods of research of social and cultural processes], 159-166. Omsk.

Krivonogov, V.P. (2008). Tofalary: Tri shaga v budushchee [Tofalars: Three Steps to the Future]. Krasnoyarsk, 198 p.

Krivonogov, V.P. (2016). Sovremennye tofalary (opyt inteval'nykh issledovanii) [Modern Tofalars (experience of interval studies)], In Novye issledovaniia Tuvy [New research of Tuva], 3 (31), 122-145.

Krivonogova, L.V. (2007). Metisatsiia tofalarov: sovremennyi etap [Métisation of the Tofalars: the present stage], In Materialy XLVII Regional'noi (III vserossiiskoi s mezhdunarodnym uchastiem) arkheologo-etnograficheskoi konferentsii studentov $i$ molodykh uchenykh Sibiri i Dal'nego Vostoka [Materials of the XLVII Regional (III All-Russian with international participation) archaeological and ethnographic conference of students and young scientists in Siberia and the Far East (Novosibirsk, April 3-4, 2007)], 308-309. Novosibirsk, Novosibirsk State Pedagogical University.

Kudriavtsev, Iu. (1927). Tsentral'noe Saiano-Karagaskoe okhotnich'e khoziaistvo [Central Sayan-Karagas hunting farm]. Moscow.

Kuryshov, A.M. (2006). Transformatsiia traditsionnogo khoziaistva evenkov i tofov Irkutskoi gubernii v kontse XIX - nachale XX vv. [Transformation of the traditional economy of the Evenki and Tofalars in the Irkutsk Governorate in the end of the $19^{\text {th }}$ - early $20^{\text {th }}$ centuries], In Istoriko-ekonomicheskie issledovaniia [Historical and economic research], 7:2, 91-110.

Mel'nikova, L.V. (1994). Tofy: istoriko-etnograficheskii ocherk [Tofalars: historical and ethnographic review]. Irkutsk, East-Siberian Book Publishing House. 
Menges, K.H. (1959a). Die tiirkischen Sprachen Siid-Sibiriens, III: Tuba (SojoD und Karagas), 1. Zur Charakteristik einer ein zelnen sibirisch-tiirkischen Gruppe, In Central Asiatic Journal, 4:2.

Menges, K.H. (1959b). Die tiirkischen Sprachen Siid sibiriens, III: Tuba (Sojoo und Karagas), 2. Zur Charakteristik einer ein zelnen sibirisch-tiirkischen Gruppe, In Central Asiatic Journal, 5:2.

Mirotvortsev, K.N. (1921). Karagasy (Statistiko-ekonomicheskii ocherk) [The Karagas people (Statistical and economic review)], In Sbornik trudov professorov $i$ prepodavatelei Irkutskogo gosuniversiteta [Proceedings of professors and lecturers of Irkutsk State University], 1:2. Irkutsk.

Mongush, M.V. (2012). Tofalary i soioty: istoriko-etnograficheskii ocherk [Tofalars and Soyots: historical and ethnographic review], In Novye issledovaniia Tuvy [New studies of Tuva], 2 (14), 62-77.

Nadeliaev, V.M. (1969). Osobennosti zvukovoi sistemy iazyka tofov [Features of the phonological system in the Tofalar language], In Materialy konferentsii "Etnogenez narodov Severnoi Azii" [Materials of the conference "Ethnogenesis of the North Asian peoples"], 1. Novosibirsk.

Pervukhin, I. (1930). Karagasy [The Karagas people], In Sovetskii Sever [The Soviet North], 2. Moscow.

Petri, B.E. (1926). Karagasskii Suglan. [The Karagas Peole's Assembly]. Irkutsk.

Petri, B.E. (1927a). Olenevodstvo u karagas [Reindeer husbandry of the Karagas people]. Irkutsk.

Petri, B.E. (1927b). Olenevodstvo u karagas [Reindeer husbandry of the Karagas people]. Irkutsk, Izd-vo "Vlast' truda".

Petri, B.E. (1927c). Okhotnich'i ugod'ia i rasselenie karagas [Hunting areas and the Karagas people settlement]. Irkutsk.

Petri, B.E. (1927d). Etnograficheskie issledovaniia sredi malykh narodov v Vostochnykh Saianakh (Predvaritel'nye dannye) [Ethnographic studies of small-numbered peoples in the Eastern Sayans (Preliminary data)], In Sbornik trudov professorov $i$ prepodavatelei Irkutskogo gosuniversiteta. Pedagogicheskii fakt [Proceedings of professors and lecturers of the Irkutsk State University. Pedagogical faculty], 12.

Petri, B.E. (1928a). Biudzet karagasskogo khoziaistva [Budget of the Karagas economy], In Izvestiia Biologo-geograficheskogo nauchno-issledovatel'skogo instituta pri Irkutskom gosuniversitete [Journal of the Biological and Geographical Research Institute of Irkutsk State University], 4:1. 
Petri, B.E. (1928b). Promysly karagas [The Karagas people occupations]. Irkutsk.

Petri, B.E. (1928c). Cherty rodovogo byta karagasov [Traits of the family life of the Karagas people]. Irkutsk.

Popov, I. (1879). Zapiski o karagasakh. O pervykh priemakh fizicheskogo vospitaniia detei u raznykh narodnostei, naseliaiushchikh Irkutskuiu guberniiu [Notes on the Karagas people. On the first methods of physical education for children of different nationalities who live in the Irkutsk Governorate]. Irkutsk.

Prelovskii, A.V. (compiler and translator) (2007). Saiam-Mergen. Antologiia tofalarskogo fol'klora [Sayan-Mergen. Anthology of the Tofalar folklore]. Moscow, Izd-vo "Novyi kliuch", 69 p.

Prelovskii, P. (1868-1869). Nizhneudinskie Karagasy [Nizhneudinsk Karagas people], In Zapiski i trudy Gubernskogo Statisticheskogo Komiteta [Notes and proceedings of the Governorate Statistical Committee], 4. Irkutsk.

Ragulina, M.V. (2008). Etnoekonomicheskie osobennosti kollektivizatsii v Tofalarii [Ethnoeconomic features of collectivization in Tofalaria], In Istoriko-ekonomicheskie issledovaniia [Historic and economic research], 2, 20-30.

Rassadin, I.V. (2000). Osobennosti traditsionnoi material'noi kul'tury saianskikh ollenevodov-tofalarov [Peculiarities of the traditional material culture of Sayan Tofalars reindeer herders], In Etnologicheskie issledovaniia: Sb. st. [Ethnological Studies: Collection of articles], 1, 131-148. Ulan-Ude, Publishing house of BSC SB RAS.

Rassadin, I.V. (2013). Novye formy sotsial'no-obshchestvennykh otnoshenii i dukhovnoi kil'tury tofalarov $\mathrm{v}$ sovetskoe vremia [New forms of social and public relations and spiritual culture of the Tofalars in Soviet times], In Vlast [Power], 1, 146-149.

Rassadin, I.V. (2013). Transformatsiia traditsionnoi pushnoi okhoty u saianskikh olenevodov tofalarov [Transformation of traditional fur hunting among the Sayan Tofalar reindeer herders], In Vestnik Buriatskogo gosudarstvennogo universiteta [Bulletin of the Buryat State University], 7, 104-110.

Rassadin, V.I. (1965). O tofalarskoi leksike (Predvaritel'nye dannye poezdki $\mathrm{k}$ tofalaram) [On the Tofalar vocabulary (Preliminary data of the trip to the Tofalar settlements), In Issledovaniia po iazyku i fol'kloru [Studies on the language and folklore], 1. Novosibirsk.

Rassadin, V.I. (1966). Leksika sovremennogo tofalarskogo iazyka [Vocabulary of thr modern Tofalar language], Avtoreferat kand. diss. [Abstract of the Thesis of Candidate of Science]. Ulan-Ude. 
Rassadin, V.I. (1968). Buriatskie leksicheskie zaimstvovaniia v tofalarskom iazyke [Buryat lexical borrowings in the Tofalar language], In Issledovanie buriatskikh govorov [Research of Buryat dialects], 2. Ulan-Ude.

Rassadin, V.I. (1969). Etapy istorii tofalarov po iazykovym dannym [Stages of the Tofalar history according to the linguistic data], In Materialy konferntsii "Etnogenez narodov Severnoi Azii" [Proceedings of the conference "Ethnogenesis of the North Asian peoples"], 1, 224-226.

Rassadin, V.I. (1971). Fonetika i leksika tofalarskogo iazyka [Phonetics and vocabulary of the Tofalar language]. Ulan-Ude, Buryat Publishing House, 252 p.

Rassadin, V.I. (1972). O razvitii tofalarsko-russkogo dvuiazychiia [On the development of Tofalar-Russian bilingualism], In Problemy dvuiazychiia $i$ mnogoiazychiia [Problems of bilingualism and multilingualism]. Moscow.

Rassadin, V.I. (1976). Ob odnom areal'nom iavlenii fonetiki tofalarskogo iazyka [On one areal phenomenon of the Tofalar language phonetics], In Proiskhozhdenie aborigenov Sibiri i ikh iazykov [Origin of the Siberia aborigines and their languages], In Materialy Vsesoiuznoi konferentsii 3-5 iunia 1976 [Materials of the All-Union conference, June 3-5, 1976].

Rassadin, V.I. (1978). Morfologiia tofalarskogo iazyka vsravnital'nom osveshchenii [Morphology of Tofalar language in comparative study]. Moscow, "Nauka", $288 \mathrm{p}$.

Rassadin, V.I. (1985). Ob organizatsii polipredikativnykh predlozhenii s podchinitel'noi sviaz'iu v tofalarskom iazyke [On the structure of polypredicative sentences with subordination in the Tofalar language], In Polypredikativnye konstruktsii $v$ iazykakh raznykh sistem: Sb. nauch. statei [Polypredicative constructions in languages of different systems: Collection of scientific articles], 3-11. Novosibirsk.

Rassadin, V.I. (1995). Tofalasko-russkii i russko-tofalarskii slovar' [The TofalarRussian and Russian-Tofalar dictionary]. Irkutsk.

Rassadin, V.I. (2005). Slovar' tofalarsko-russkii i russko-tofalarskii [Dictionary of the Tofalar-Russian and Russian-Tofalar], In Tofa-Orus - Orus-Tofa soottary: Textbook for schools. Saint-Petersburg, "Drofa", 295 p.

Rassadin, V.I. (2008). Tofalary [The Tofalars], In Tiurkskie narody Vostochnoi Sibiri [The Turkic peoples of Eastern Siberia], 262-333. Moscow, "Nauka".

Rassadin, V.I. (2009). Istoriia tofalarskoi pis'mennosti [History of the Tofalar writing system], In Problemy mongolovednykh i altaisticheskikh issledovanii: Materialy 
mezhdunarod. konf., posv. iubileiu prof. V.I. Rassadina [Aspects of Mongolian and Altai Studies: Materials of International conference, dedicated to the anniversary of prof. V.I. Rassadin], 6-9. Elista, Kalmyk State University.

Rassadin, V.I. (2013). O kul'te medvedia u tofalarov [On the bear cult of the Tofalars], In Novye issledovaniia Tuvy [New studies of Tuva], 3 (19), 88-94.

Rassadin, V.I. (2015). Tofalarskii iazyk i ego mesto v sisteme tiurkskikh iazykov [The Tofalar language and its place in the system of Turkic languages]. Moscow, "Directmedia".

Rassadin, V.I. Shibkeev, V.N. (1989). Tofa bukvar': Tofalarskii bukvar' dlia pervogo klassa tofalarskikh shkol [Tofa primer: Tofalar primer for the first class of Tofalar schools]. Irkutsk.

Sergeev, M.A. (1940). Tofalary segodnia (K istorii natsional'nogo stroitel'stva) [Tofalars today (On the history of national foundation)], In Sovetskaia etnografia [Soviet ethnography], 4. Moscow-Leningrad.

Sergeev, M.A. (1956). Tofalary - Narody Sibiri [Tofalars - Peoples of Siberia], ed. by M.G. Levin, L.P. Potapov. Moscow-Leningrad.

Sergeyev, M.A. (1964). The Tofalars, In The Peoples of Siberia. Chicago, University of Chicago, 474-484.

Shagdarov, L.D., Rassadin, V.I. (1968). Ob upotreblenii tofalarami buriatskogo iazyka [On the use of the Buryat language by the Tofalars], In Issledovanie buriatskikh govorov [Research of Buryat dialects], 2. Ulan-Ude.

Sherkhunaev, R.A. (1975). Skaski i skazochniki Tofalarii [Fairy tales and storytellers in Tofalaria]. Kyzyl.

Smirnov-Sibirskii, Al. (1932a). V strane karagas [In the country of the Karagas people]. Moscow.

Smirnov-Sibirskii, Al. (1932b). Sredi karagasov [Among the Karagas people], In Vestnik znaniia [Bulletin of knowledge], 11. Leningrad.

Solov'ev, D. (1920). Saianskii promyslovo-okhotnichii raion i sobolinyi promysel $\mathrm{v}$ nem [Sayan hunting and game area and sable take in it], In Trudy ekspeditsii po izucheniiu sobolia i issledovaniiu sobolinogo promysla. Ser. 2. Saianskaia [Proceedings of the Expedition on the study of sable and examination of sable take, Ser. 2. Sayan]. Petrograd.

Stubendorf, Iu.P. (1854). O karagassakh [On Karagas people], In Vestnik Imperatorskogo Russkogo geograficheskogo obshchestva [Bulletin of the Imperial Russian Geographical Society], 12, 2. 
Vasil'ev, N.V. (1910). Kratkii ocherk byta karagasov [A short review on the life of the Karagas people], In Etnograficheskoe obozrenie [Ethnographic Review], 84-85, 1-2. Moscow.

Vasilevich, G.M., Levin, M.G. (1951). Tipy olenevodstva i ikh proiskhozhdenie [Types of reindeer herding and their origin], In Sovetskaia etnografiia [Soviet Ethnography], 1.

Weinstein, S.I. (1960). K voprosu o saianskom tipe olenevodstva i ego vozniknovenii [On the issue of the Sayan type of reindeer herding and its occurrence], In Kratkie soobshcheniia Instituta etnografii [Brief communications of the Institute of Ethnography of the USSR Academy of Sciences], 34.

Weinstein, S.I. (1968). K voprosu o proiskhozhdenii olenevodstva (Ob odnoi paralleli v material'noi kul'ture kirgizov i saianskikh olenevodov) [On the origin of reindeer husbandry (On one analogy in the material culture of the Kirghiz and Sayan reindeer herders)], In Istoriia, arkheologiia i etnografiia Srednei Azii [History, archeology and ethnography of Central Asia]. Moscow.

Weinstein, S.I. (1968). Rodovaia struktura i patronimicheskaia organizatsiia u tofalarov (do nachala XX v.) [The kin structure and patronymic organization of the Tofalars (prior to the beginning of the $20^{\text {th }}$ century)], In Sovetskaia etnografiia [Soviet ethnography], 3.

Weinstein, S.I. (1970). Sotsial'naia organizatsiia saianskikh olenevodov-okhotnikov (tofalary) [Social organization of the Sayan reindeer herders-hunters (Tofalars)], In Obshchestvennyi stroi u narodov Severnoi Sibiri (XVII-nachalo XX v.) [Social system of the peoples of Northern Siberia (17 th - early 20 th century), chapter 10. Moscow.

Zalesskii, N.V. (1898). K etnografii i antropologii karagasov [On ethnography and anthropology of the Karagas people], In Trudy Antropologicheskogo obshchestva pri Voenno-meditsinskoi akademii [Proceedings of the Anthropological Society at the Military Medical Academy], 3, Saint-Petersburg.

Ziker, J.P. (2003). Assigned territories, family/clan/communal holdings, and common-pool resources in the Taimyr autonomous region, northern Russia, In Human Ecology, 31.3, 331-368.

Ziker, J.P. (2002). Peoples of the tundra: Northern Siberians in the post-communist transition. Waveland Press. 


\title{
Оленные люди, живущие возле озера Байкал: процессы этнокультурной идентичности современных тофаларов \\ (Северная Азия, Восточная Сибирь)
}

\author{
В.П. Кривоногов \\ Сибирский федеральный университет \\ Россия, 660041, Красноярск, пр. Свободныий, 79
}

\begin{abstract}
В статье представлены результаты интегрального исследования процессов этнической и культурной идентификачии тофаларов, коренного малочисленного народа Сибири, принадлежащего к тюркской группе и компактно проживающего на территории Иркутской области.

Основные методы анализа - это интервальные полевые исследования, сделанные с определенным временным промежутком, сравнительные исследования исторической динамики этнической трансформации тофаларов. Применялся критический анализ научных источников. Была сделана интерпретация полученных результатов и определенные прогнозы этнической, лингвистической и культурной трансформации тофаларов в ХХІ веке.
\end{abstract}

В качестве основного вывода следует отметить, что рост числа тофаларов сменился стабилизачией. Тофалары составляют более половины населения Тофаларии. Однако что касается языка, можно констатировать его стремительный уход из жизни народа; здесь процессы однолинейны - с каждым десятилетием языковой показатель быстро приближается к нулю, по мере смены поколений. В связи с ограниченным количеством инонационального населения количество смешанных браков перестало расти и даже начало сокращаться, однако оставалось на достаточно высоком уровне. В результате быстро нарастает доля этнически и антропологически смешанного населения в составе тофаларов, в младших возрастных группах практически все тофалары-метисы.

Ключевые слова: Восточная Сибирь, Евразия, коренные народы, тофалары, этническая идентичность, культурная идентичность, лингвистические процессы, интервальные исследования, полевые исследования, статистика.

Научная специальность: 24.00.00 - культурология. 